\title{
ENZYMATICALLY ACTIVE, CROSS-LINKED PIG HEART LACTATE DEHYDROGENASE CRYSTALS
}

\author{
by \\ STEPHEN J. BAYNE \\ MARTIN OTTESEN \\ Department of Chemistry - Carlsberg Laboratory \\ Gamle Carlsberg Vej 10 - DK-2500 Copenhagen, Valby
}

Keywords: Lactate dehydrogenase, cross-linked crystals, amino acid composition, urea.

Pig heart lactate dehydrogenase crystals were cross-linked with octanediimidic acid dimethylester. The resulting cross-linked crystals were insoluble in dilute phosphate buffer and had retained a high specific activity. Amino acid analyses showed that about twelve lysine residues out of twenty-three per subunit had been chemically modified. The cross-linked crystals showed increased stability in urea compared to the soluble enzyme. The differences caused by the cross-linking process to the properties of the enzyme are briefly discussed.

\section{INTRODUCTION}

In studies involving the catalytic properties of enzyme crystals, the initial investigations could only be carried out on crystals in equilibrium with their solvent $(7,15)$. However, with the development of methods for cross-linking crystals, the insoluble crystalline preparations thus formed were studied in dilute buffer solu- tion under conditions used for soluble enzymes $(11,12,16)$. The majority of the studies involving cross-linked enzyme crystals have been restricted to hydrolytic enzymes and to the best of our knowledge, the preparation of cross-linked dehydrogenase crystals has not been reported previously.

The present report describes the cross-linking 
of pig heart lactate dehydrogenase (LDH)*) crystals with the bifunctional reagent, octanediimidic acid dimethylester (ODD)*). The absence of metal ion requirement as well as a lack of interaction between its binding sites (10) renders this enzyme an attractive model for a study of the effect of cross-linking of subunits on its kinetic parameters. A bifunctional diimidate was chosen for cross-linking as it has been shown to react specifically with $\mathrm{N}$-terminal residues and lysine $\varepsilon$-amino groups of proteins (4). The current investigations have revealed that cross-linked crystals of LDH not only possess high specific activity relative to the soluble enzyme but also manifest a greater degree of stability upon exposure to urea. Some differences between the properties of the crosslinked crystals and those of the soluble enzyme in dilute buffer are discussed.

\section{MATERIALS AND METHODS}

\subsection{Materials}

LDH (EC 1.1.1.27) (batch no. 7365116) was obtained as an ammonium sulphate suspension from Boehringer, Mannheim. NADH disodium salt was a commercial product of the Carlsberg Breweries, Copenhagen. Sodium pyruvate was supplied by Boehringer. ODD was obtained from Pierce, Rockford, Illinois, U. S. A. All other reagents were of analytical grade. Deionised water was used throughout the studies.

\subsection{Methods}

\subsubsection{Preparation of cross-linked LDH crystals}

All steps were carried out at room temperature unless otherwise stated. In a typical preparation, $\mathrm{LDH}(5 \mathrm{mg})$ in $500 \mu \mathrm{l} 3.2 \mathrm{M}$-ammonium sulphate solution, pH6, was centrifuged at $26000 \mathrm{~g}$ for $20 \mathrm{~min}$. The supernatant was removed and the crystals were suspended and washed twice with $500 \mu \mathrm{l}$ aliquots of sodium sulphate solution ( $40 \mathrm{~g} \mathrm{Na}_{2} \mathrm{SO}_{4} .10 \mathrm{H}_{2} \mathrm{O}$ dissolved in $50 \mathrm{ml} 50 \mathrm{mM}$ sodium pyrophosphate, $\mathrm{pH} 8.5$, and titrated to $\mathrm{pH} 8.5$ with $1.0 \mathrm{M}-\mathrm{NaOH}$ ). Following removal of the second supernatant, the crystals were transferred to a measuring cylinder $(1.5 \times 7 \mathrm{~cm})$ with the aid of saturated sodium sulphate solution $\left(25^{\circ} \mathrm{C}\right.$, in $50 \mathrm{mM}$-sodium pyrophosphate, $\mathrm{pH} 8.5$, and titrated to $\mathrm{pH} 8.5$ with $1.0 \mathrm{M}$ $\mathrm{NaOH}$ ). Sufficient of the same solution was added to give a final protein concentration of about $1 \mathrm{mg} / \mathrm{ml}$.

Cross-linking was achieved by adding $9 \mu \mathrm{l}$ of a freshly prepared solution of ODD $(10 \mathrm{mg}$ dissolved in $100 \mu \mathrm{l}$ phosphate buffer, $\mathrm{pH} 7.0$, ionic strength 0.1 (1), referred to in the following as phosphate buffer) to the rapidly stirred suspension of crystals. The concentration of ODD in the reaction mixture was stoichiometric with respect to the $\varepsilon$-amino groups of the lysine residues present in the protein. Slow stirring was continued for $200 \mathrm{~min}$. Following addition of an equal volume of phosphate buffer, the suspension was mixed and centrifuged at 26000 $\mathrm{g}$ for $10 \mathrm{~min}$. The crystals were collected and washed by suspension in $5 \mathrm{ml}$ aliquots of phosphate buffer and centrifugation as before, until the supernatant showed no LDH activity. The crystals were suspended in $2 \mathrm{ml}$ phosphate buffer and separated into three fractions of varying crystal sizes by differential centrifugation. The first fraction (batch $A$ ) was obtained by centrifugation at $290 \mathrm{~g}$ for $5 \mathrm{~min}$ at $4^{\circ} \mathrm{C}$. The supernatant was then centrifuged at $1160 \mathrm{~g}$ for 5 min at $4^{\circ} \mathrm{C}$ to obtain the second fraction (batch $B$ ). The second supernatant was finally centrifuged at $2600 \mathrm{~g}$ for $5 \mathrm{~min}$ at $4^{\circ} \mathrm{C}$ to achieve the third fraction (batch C). Each of the above fractions was suspended in $2 \mathrm{ml}$ aliquots of phosphate buffer. The supernatant of the third centrifugation was discarded as it showed no LDH activity.

\subsubsection{Effect of urea on the activity of soluble $L D H$ and cross-linked crystal batch $A$. \\ Two sets of experiments were carried out. The first involved a study of the effect of $2 M$-urea at $0^{\circ} \mathrm{C}$ and $23^{\circ} \mathrm{C}$ on the stability of soluble $\mathrm{LDH}$ and of cross-linked crystals of batch A. Ali- quots were withdrawn at various time intervals over a period of $5 \mathrm{~h}$ and assayed for residual}

\footnotetext{
* Abbreviations: LDH, pig heart lactate dehydrogenase; ODD, octanediimidic acid dimethylester; NADH, nicotinamide - adenine dinucleotide, reduced.
} 
LDH activity. The second set of experiments involved a study of the effect of increasing urea concentrations on the activity of soluble LDH and cross-linked crystals of batch $\mathrm{A}$ after 60 min incubation, either at $0^{\circ}$ or at $23^{\circ} \mathrm{C}$.

\subsubsection{Activity measurements of soluble and cross- linked $L D H$}

Activity was measured by recording the oxidation of $\mathrm{NADH}$ at $\mathrm{E}_{340 \mathrm{~nm}}$. The assay cuvette contained phosphate buffer $(3.0 \mathrm{ml})$, NADH solution $(6 \mathrm{mM}, 0.1 \mathrm{ml})$ and sodium pyruvate solution $(23 \mathrm{~m} M, 0.1 \mathrm{ml})$. The reaction was initiated by the addition of $5 \mu$ l enzyme solution or $5 \mu \mathrm{l}$ enzyme crystal suspension suitably diluted. Specific activity was expressed as $\mu \mathrm{mol}$ NADH oxidised per min per mg enzyme or per mg enzyme crystals (units/mg).

\subsubsection{Amino acid analyses}

Amino acid analyses were carried out using the Durrum Model 500 amino acid analyser on samples of LDH which had been hydrolysed for 24, 48 and $96 \mathrm{~h}$ by constant boiling $\mathrm{HCl}$ in sealed evacuated tubes at $110^{\circ} \mathrm{C}$. The threonine and serine contents were established by linear extrapolation. Valine and isoleucine contents were determined as the values obtained after 96 $h$ hydrolysis.

The tryptophan content of the protein was determined by two different methods. The first procedure was as described by EDELHOCH (2). The second method was essentially that described by LIU \& CHANG (8) using the short column $(0.9 \times 11 \mathrm{~cm})$ of the Spinco Model 120 amino acid analyser. The tryptophan content was determined by linear extrapolation.
The cysteine content was determined by the method of HIRS (3) with the modification that excess reagents were removed by an air stream at $45^{\circ} \mathrm{C}$ instead of freeze-drying. This caused destruction of tyrosine residues.

The extent of lysine residue modification by ODD cannot be obtained by straightforward hydrolysis of the cross-linked crystals. The indirect procedure, described by STARK (13) and SVENDSEN (14), in which the crystals were first carbamylated with potassium cyanate, was used. The carbamylated crystals were washed free of excess reagent with phosphate buffer and deionised water before being dried in an air stream at $45^{\circ} \mathrm{C}$. After hydrolysis of the carbamylated crystals as described above for native $\mathrm{LDH}$, the initial homocitrulline content and hence the number of lysines not involved in cross-linking was determined by extrapolation. Under these conditions, about $25 \%$ of the homocitrulline formed was found to be split in the first $24 \mathrm{~h}$. The alanine content was used to calculate the amount of protein in the crystals.

\section{RESULTS AND DISCUSSION}

\subsection{Effect of cross-linking on the specific activity and lysine content of LDH crystals.}

The specific activities of batches, $A, B$ and $C$ of the cross-linked crystals are presented in Table 1. The separation described was rather crude and each crystal batch contained a range of crystal sizes. The activities measured thus represent an average of the activities of all individual crystals within that batch.

The results showed that about $87 \%$ of the enzymatic activity of the cross-linked crystals

Table I

Effect of cross-linking on the specific activity of LDH crystals.

\begin{tabular}{|c|c|c|c|c|}
\hline $\begin{array}{c}\text { Crystal } \\
\text { Batch }\end{array}$ & $\begin{array}{c}\text { Specific } \\
\text { Activity } \\
\text { (units/mg) }\end{array}$ & $\begin{array}{c}\text { Total Protein } \\
\text { per batch (mg) }\end{array}$ & $\begin{array}{c}\text { Total Activity } \\
\text { (units per batch) }\end{array}$ & $\begin{array}{c}\text { \% Retained } \\
\text { Activity }\end{array}$ \\
\hline A & 84 & 1.87 & 157 & 19 \\
B & 152 & 1.14 & 172 & 23 \\
\hline
\end{tabular}


was associated with batches $\mathrm{A}$ and $\mathrm{B}$. Furthermore, batch A crystals contained 50\% more protein than those of batch $B$ even though the amount of total enzymatic activity was almost the same in both batches. The lower specific activity of batch $\mathrm{A}$ crystals could arise from either one or a combination of the following factors: (a) the presence of inactive enzyme in the crystals; (b) the occurrence of catalysis being restricted to active sites at the crystal surface; and (c) the differences in the extent of cross-linking. Since the smallest cross-linked crystals (batch C) do not have the highest specific activity (see Table 1), the second factor does not appear to be responsible for the observations.

The amino acid composition of LDH shown in Table II, is in reasonable agreement with the literature data $(5,9)$. The tryptophan content had not been determined in previous investiga- tions. The amino acid compositions of the various cross-linked crystal preparations are in good agreement with those for $\mathrm{LDH}$ recorded in the literature. A significant feature of these analyses is the similar extent of lysine modification in all the three batches of cross-linked crystals, regardless of their size. Thus it would appear that the lower specific activity in batch A can not be attributed to the difference in the extent of cross-linking.

The specific activities reported in Table I were obtained using soluble enzyme assay conditions. However, preliminary determinations of the Michaelis parameters showed that the $\mathrm{K}_{\mathrm{m}}$ values for $\mathrm{NADH}$ had increased at least eighteen-fold relative to those for the soluble enzyme and the observed rates for the cross-linked crystals were thus below the real $\mathrm{V}_{\max }$. In addition, diffusional effects probably contribute to the lowering of the activities obtained

Table II

Amino acid composition of LDH and cross-linked crystal batches $A, B$ and $C$.

The amino acid composition is expressed as residues per subunit, molecular weight, 36000 (6).

The tryptophan and cysteine contents were determined as described in the text.

\begin{tabular}{|c|c|c|c|c|c|c|}
\hline & \multicolumn{3}{|c|}{ Soluble Enzyme } & \multicolumn{3}{|c|}{$\begin{array}{c}\text { Cross-linked } \\
\text { Crystals }\end{array}$} \\
\hline & Experimental & $\begin{array}{l}\text { Holbrook } \\
\text { et al. (5) }\end{array}$ & $\begin{array}{c}\text { Pfleiderer } \\
\text { \& Mella (9) }\end{array}$ & A & B & $\mathrm{C}$ \\
\hline Aspartate & 37.8 & 34 & 40 & 35.5 & 36.5 & 34.9 \\
\hline Threonine & 15.2 & 15 & 18 & 14.6 & 14.8 & 14.0 \\
\hline Serine & 25.7 & 24 & 26 & 24.1 & 25.4 & 24.2 \\
\hline Glutamate & 34.9 & 31 & 38 & 33.9 & 35.2 & 34.6 \\
\hline Proline & 12.2 & 12 & 12 & 10.8 & 10.9 & 10.7 \\
\hline Glycine & 24.6 & 24 & 26 & 25.0 & 25.3 & 24.3 \\
\hline Alanine & 18.7 & 19 & 19 & 19.2 & 19.2 & 19.2 \\
\hline Cysteine & 5.2 & 4 & 4 & - & - & - \\
\hline Valine & 37.1 & 37 & 36 & 37.1 & 38.1 & 38.1 \\
\hline Methionine & 7.3 & 9 & 8 & 7.4 & 7.6 & 7.8 \\
\hline Isoleucine & 19.9 & 21 & 24 & 20.8 & 21.4 & 21.0 \\
\hline Leucine & 35.5 & 34 & 37 & 34.6 & 35.4 & 36.0 \\
\hline Tyrosine & 7.6 & 7 & 8 & 6.6 & 7.7 & 7.7 \\
\hline \multicolumn{7}{|l|}{ Phenyla- } \\
\hline lanine & 4.9 & 5 & 5 & 5.0 & 4.9 & 5.0 \\
\hline Histidine & 7.2 & 7 & 8 & 6.4 & 6.6 & 6.4 \\
\hline Lysine & 22.9 & 23 & 26 & - & - & - \\
\hline Tryptophan & 5.6 & - & - & - & - & - \\
\hline Arginine & 7.6 & 9 & 9 & 8.0 & 7.8 & 7.7 \\
\hline \multicolumn{7}{|l|}{ Homoci- } \\
\hline trulline & - & - & - & 12.0 & 11.6 & 11.5 \\
\hline
\end{tabular}


owing to the crystal lattice restricting access of the substrate and coenzyme to the active centres of the enzyme molecules.

The method of cross-linking described in Section 2.2.1 was the final result of several preliminary experiments involving a variation of the ODD concentration and also the time of cross-linking. A lower ODD concentration than the one reported here resulted in cross-linked crystals with only 4 lysines modified, which dissolved on washing with phosphate buffer. With a higher ODD concentration than that used in Section 2.2.1, an insoluble amorphous LDH with 17 lysines modified was obtained. Using the ODD concentration described in Section 2.2.1 but a shorter cross-linking time $(60 \mathrm{~min})$ similarly gave crystals which dissolved in phosphate buffer, whereas a longer cross-linking time ( $4 \mathrm{~h})$ gave crystals which were partially amorphous in appearance. Amorphous in this context means crystals that have lost their sheen, have lost their ability to rotate the plane of polarised light, have low activities and are difficult to pipette owing to "clumping ${ }_{\text {". }}$

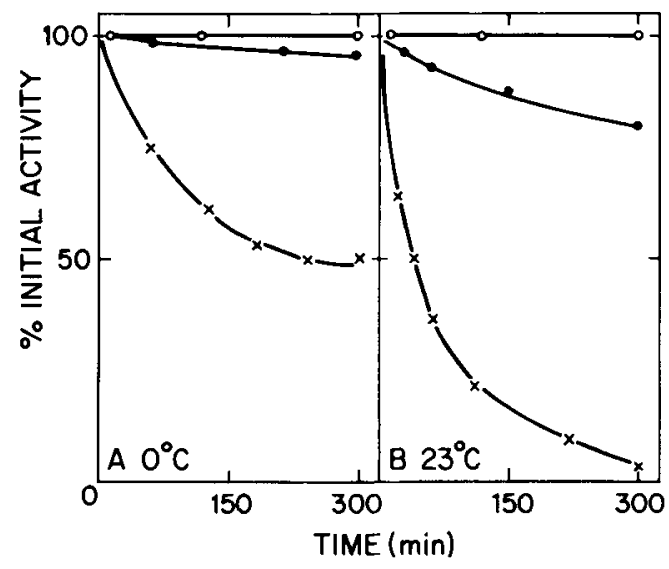

Figure $1 A$ and B. Effect of $2 M$-urea on the activity of soluble LDH and cross-linked crystals.

For soluble LDH studies, $25 \mu \mathrm{l}(10 \mu \mathrm{g}) \mathrm{LDH}$ solution were added to $1 \mathrm{ml} 2 M$-urea in phosphate buffer; for crystal studies, $25 \mu \mathrm{l}(47 \mu \mathrm{g})$ batch A crystals were added to $250 \mu \mathrm{l} 2 \mathrm{M}$-urea in phosphate buffer. $10 \mu \mathrm{l}$ aliquots of the solution $(x)$ or suspension (0) were withdrawn at intervals and assayed for residual LDH activity. In the absence of urea, both the soluble and the cross-linked crystals lose no activity at either temperature over the time period studied $(O)$.

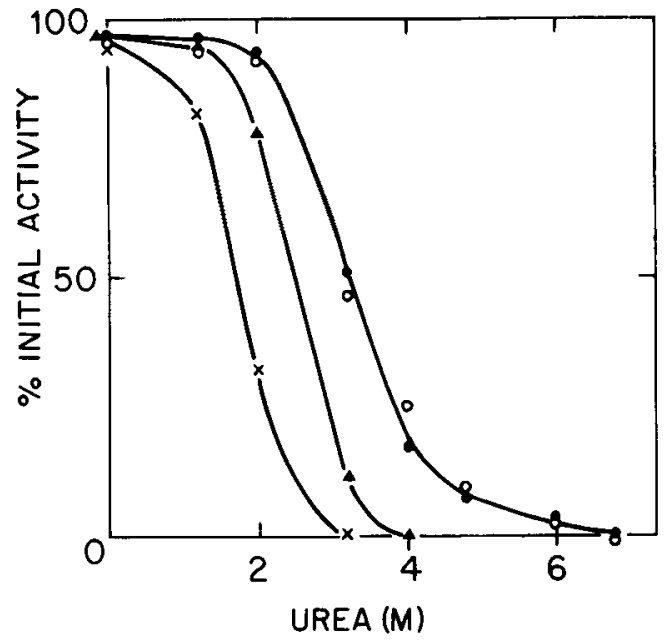

Figure 2. Effect of increasing urea concentrations on the activity of soluble LDH and batch A crystals.

The method was essentially as described in Fig. 1. The phosphate buffer contained various concentrations of urea. The $\mathrm{LDH}$ solutions $\left(\triangle, 0^{\circ} \mathrm{C} ; \mathrm{x}\right.$, $\left.23^{\circ} \mathrm{C}\right)$ or crystal suspensions $\left(0,0^{\circ} \mathrm{C} ; 0,23^{\circ} \mathrm{C}\right)$ were incubated for $60 \mathrm{~min}$ at either $0^{\circ} \mathrm{C}$ or at $23^{\circ} \mathrm{C}$, respectively.

\subsection{Effect of urea on the activity of soluble $L D H$ and crystal batch $A$.}

The effect of $2 M$-urea on the activity of soluble LDH and batch $A$ crystals at $0^{\circ} \mathrm{C}$ and $23^{\circ} \mathrm{C}$ is shown in Figs. $1 \mathrm{~A}$ and $1 \mathrm{~B}$ respectively. In the absence of urea, both soluble LDH and batch $\mathrm{A}$ crystals retained their original activities at $0^{\circ} \mathrm{C}$ and $23^{\circ} \mathrm{C}$ over the time period studied. In the presence of urea at $23^{\circ} \mathrm{C}$, the crystals have a five-fold higher activity compared to the soluble enzyme; at $0^{\circ} \mathrm{C}$, they appear to be even more stable retaining ten-fold more activity than the soluble enzyme.

The effect of increasing the urea concentration on the activities of soluble LDH and batch A crystals at $0^{\circ} \mathrm{C}$ and $23^{\circ} \mathrm{C}$ is shown in Fig. 2 . After $60 \mathrm{~min}$ incubation in $3.2 \mathrm{M}$-urea at both $0^{\circ} \mathrm{C}$ and at $23^{\circ} \mathrm{C}$, the crystals still showed $50 \%$ of their original activity while soluble LDH showed none of its original activity at $23^{\circ} \mathrm{C}$ and only $25 \%$ at $0^{\circ} \mathrm{C}$. Batch A crystals were still slightly active after $60 \mathrm{~min}$ incubation in $6 \mathrm{M}$ urea at $23^{\circ} \mathrm{C}$.

The retention of a considerable amount of catalytic activity in the cross-linked crystals in 
urea solutions may simply be a reflection of the restriction imposed on the dissociation of the active tetramer to its inactive momomers. Alternatively, the possibility that cross-linking of the subunits stabilises their conformations such that they become more resistant to urea could provide another explanation for the above observations.

\section{ACKNOWLEDGEMENTS}

We thank Dr. T. Viswanatha for his critical reading of the manuscript and helpful suggestions. One of the authors (S. J. B.) wishes to thank the entire laboratory staff for their hospitality and patience during his stay. The receipt of a Royal Society European Science Exchange Programme Fellowship is gratefully acknowledged.

\section{REFERENCES}

1. Data, S. P. \& A. K. Gryzbowsk1: Chemical Data. In: S. Long, ed., The Biochemists Handbook, p. 32 (1961)

2. EDElHoCH, H.: Spectrophotometric determination of tryptophan and tyrosine in proteins. Biochemistry 6: 1948-1954 (1967)

3. Hirs, C. H. W.: Performic acid oxidation. In: C. H. W. Hirs, ed., Methods Enzymol. XI, pp. 197 199 (1967)

4. Hunter, M. J. \& M. L. LuDwiG: The reaction of imidoesters with proteins and related small molecules. J. Amer. Chem. Soc. 84: 3491-3504 (1962)

5. Holbrook, J. K., A. Liljas, S. J. Steindel \& M. G. Rossmann: Lactate Dehydrogenase. In: P. D. Boyer, ed., The Enzymes, Vol. XI, p.203 (1975)
6. JAENICKE, R. \& S. KNOF: Molecular weight and quaternary structure of lactic dehydrogenase. Eur. J. Biochem. 4: 157-163 (1968)

7. KALLOS, J.: Catalytic activity of chymotrypsin in the crystalline state. Biochim. Biophys. Acta 89: 364-366 (1964)

8. LiU, T.-Y. \& Y. H. Chang: Hydrolysis of proteins with toluene sulphonic acid. Determination of tryptophan. J. Biol. Chem. 246: 2842-2848 (1971)

9. Pfleiderer, G. \& K. Mella: Primary structure of pig heart and muscle lactate dehydrogenase. In: D. Shugar, ed., Enzymes and Isoenzymes. Structure and Function 18: 151-156 (1970)

10. Schmid, F., H.-J.Hinz \& R. JAENickE: Detection of absorption changes of pig heart lactate dehydrogenase in the wavelength range between $260 \mathrm{~nm}$ and $320 \mathrm{~nm}$ on ternary complex formation with NAD ${ }^{+}$and oxalate. Hoppe-Seyler's Z. Physiol. Chem. 357: 241-245 (1976)

11. Sluyterman, L. A. Ae. \& J. M. De Graaf: The activity of papain in the crystalline state. Biochim. Biophys. Acta 171: 277-287 (1969)

12. Spilburg, C. A., J. L. Bethune \& B. L. Vallee: The physical state dependence of carboxypeptidase $A_{\alpha}$ and $A \gamma$ kinetics. Proc. Natl. Acad. Sci. 71:3922-3926 (1974)

13. Stark, G. R., W. H. Stein \& S. Moore: Reactions of the cyanate present in aqueous urea with amino acids and proteins. J. Biol. Chem. 235: 3177-3181 (1960)

14. SVENDSEN, 1.: Studies on the carbamylation of subtilisin type Novo. Compt. Rend. Trav. Lab. Carlsberg 36: 235-246 (1967)

15. Theorell, H., B. Chance \& T. Yonetani: Effect of crystallisation on the reactivity of horse liver alcohol dehydrogenase. J. Mol. Biol. 17: 513-524 (1966)

16. VinCENTELLI, J., Y. LOOZE \& J. LéONIS: A comparative study of the thermal denaturation parameters of lysozyme in the dissolved and crystalline state. Biochim. Biophys. Acta 427: 38 43 (1976) 